Juli-Anna Aerila \& Marjaana Soininen

\title{
Fiktiivinen kirjallisuus nuoren kasvun tukijana ja kulttuurienvälisen kasvun välineenä
}

\section{Johdanto}

Tyttöjen ja poikien lukuharrastuksen ja lukutaidon väliset erot ovat Suomessa OECDmaiden suurimpia, lukemista harrastavien määrä on pienentynyt, ja luetun tulkinnan ja ymmärtämisen taidot ovat heikentyneet. Peruskoululaisten lukemiseen liittyviin ongelmiin on monia syitä. Yksi on varmasti se, että fiktiivistä kirjallisuutta ei arvosteta riittävästi tai koeta riittävän hyödylliseksi. Jo ensimmäisessä PISA-testissä vuonna 2000 fiktion lukemisen taidoista kertovat tutkimustulokset herättivät ihmetystä. Linnakylä $(2004,87)$ perusteli nuorten yllättävän heikkoa menestystä fiktiivisten tekstien tulkinnassa sillä, että tuon osa-alueen tehtävät saattoivat olla testissä vaikeampia kuin muiden osa-alueiden tehtävät. Vastaavia tuloksia on saatu myös kansallisista tutkimuksista, joissa on kiinnitetty huomiota fiktioon liittyvien tehtävien ratkaisemisen ongelmiin (Lappalainen 2001, 130). Peruskoululaisten puutteelliset taidot fiktiivisten tekstien tulkinnassa ovat yllättäviä myös siinä mielessä, että perusopetuksessa luetaan paljon juuri fiktiivisiä tekstejä.

Fiktion lukemiseen ja ymmärtämiseen liittyvät ongelmat kertovat siitä, että fiktiivisiä tekstejä luetaan enimmäkseen mekaanisen lukutaidon, erilaisten tietoteksteihin liittyvien lukustrategioiden ja omaehtoisen lukemisen kehittämistarkoituksessa. Oppilaille ei hahmotu fiktiivisen kirjallisuuden lukemisen omalajisuus ja merkitys kasvun välineenä. Peruskoululaisilla onkin kovin välineellinen käsitys lukutaidosta, ja he kokevat, että fiktiivisen kirjallisuuden lukemisen suurin hyöty on lukutaidon paraneminen ja parempi koulumenestys, ei oman ja muiden elämän ymmärtäminen tai elämästä oppiminen. (Aerila 2010, 190-195; Linna 1999, 29.)

Kun fiktiota käytetään lapsen ja nuoren kasvun tukemiseen, puhutaan kirjallisuuskasvatuksesta. Tällöin lukemisen tavoitteena on oppilaan päättelytaitojen kehittäminen, arvoja koskevan ajattelun edistäminen ja minäidentiteetin vahvistuminen sekä yleisinhimillisen ja yhteiskunnallisen todellisuuden ymmärtäminen (Julkunen 1997, 28; Toivonen 1998, 67-68, 232-233). Perusopetuksessa fiktiota olisi mahdollista käyttää nykyistä monipuolisemmin ja tehokkaammin, mutta opettajilta puuttuu usein riittävä kirjallisuuden tuntemus ja sopivat opetusmenetelmät. Tällä hetkellä fiktiota hyödynnetään perusopetuksessa vähän ja pääasiassa äidinkielen ja kirjallisuuden tunneilla (Turunen 1999, 40-41). Yhdysvalloissa kasvatustieteen sekä kirjallisuuden opiskeli- 
joita koulutetaan valitsemaan, analysoimaan, arvioimaan ja käyttämään tehokkaasti opetuksessa hyödynnettävää fiktiota (Norton 2009, 2). Suomessa tällaisia käytäntöjä ei vielä ole (Aerila, Soininen \& Merisuo-Storm 2013).

Tässä artikkelissa kuvataan fiktion merkitystä ja mahdollisuuksia osana nuorten kasvua sekä heidän maailmankuvaansa liittyvien käsitysten ja arvojen arviointia. Esimerkkinä käytetään suvaitsevaisuus- tai monikulttuurisuuskasvatusta, johon erityisesti Yhdysvalloissa on jo kehitetty opetusmenetelmiä. Monikulttuuriseen lasten- ja nuortenkirjallisuuteen liittyy paljon tutkimusta ja näkökohtia, jotka ovat hyödyllisiä myös muussa kirjallisuuskasvatuksessa.

Monikulttuurisuuskasvatus on Suomessa vielä varsin jäsentymätöntä, eikä siihen soveltuvia menetelmiä ole meillä juuri kehitetty. Lisäksi monikulttuurisuuskasvatuksen tarpeet vaihtelevat Suomessa alueellisesti paljon. (Räsänen 2002.) Monikulttuurinen lasten- ja nuortenkirjallisuus näyttää kuitenkin soveltuvan sekä sellaisille ryhmille, joilla on paljon kokemuksia monikulttuurisuudesta, että niille, joilla ei kokemusta ilmiöstä juuri ole. Sopivan kirjallisuuden valinnassa on vain oltava huolellinen. (Aerila 2010, 183-190.)

\section{Fiktiivisen kirjallisuuden merkitys nuoren kasvun tukemisessa}

Fiktiiviset tekstit eivät kerro faktoja kuten tietotekstit, mutta ne liittyvät läheisesti maailman ymmärtämiseen, ja niillä on lähes aina yhteys tekstin ulkopuoliseen todellisuuteen. Fiktion lukijalla on omat kokemuksensa maailmasta ja elämästä, mutta fiktiota lukemalla voi nähdä ja ymmärtää asioita, joita ei ole elämässään kohdannut. (Lammenranta 1989, 200-201.)

Fiktion ymmärtäminen vaatii enemmän kuin tietotekstin ymmärtäminen, sillä tiedonkäsittelytaitojen lisäksi lukija tarvitsee mielikuvitusta ja tunteita. Ymmärtääkseen fiktiota lukijan on kyettävä kuvittelemaan ja kokemaan siinä kuvatut ihmiset, tilanteet ja tapahtumat. (Lammenranta 1989, 200-201.) Fiktio tarjoaa mahdollisuuksia kokea ja selkiyttää erilaisiin tilanteisiin liittyviä tunteita, jolloin lukija pystyy erottamaan ne myös todellisessa elämässä. Jotta fiktio lisäisi ymmärrystä maailmasta, sen on kuvattava sellaisia tilanteita, joihin lukija voi kuvitella erilaisissa elämänvaiheissa joutuvansa. Lukemalla kuvauksia tärkeistä elämänvaiheista oppii tuntemaan itseään, muita ihmisiä ja erilaisten tilanteiden herättämiä myönteisiä tai kielteisiä tunteita. Tämä saattaa auttaa lukijaa ymmärtämään, mikä on omassa elämässä tavoittelemisen arvoista. (Lammenranta 1989, 202-205; Pahkinen 2002, 10.)

Tunteiden tunnistaminen ja käsittely on keskeistä Rosenblattin lukemisen transaktioteoriassa. Hänen (1978, 23-25) mukaansa lukemista on kahdenlaista: esteettistä tai efferenttiä. Esteettistä lukeminen on silloin, kun päähuomio on lukutilanteessa ja lukijalle on tärkeää, mitä hän kokee ja tuntee lukiessaan. Efferentissä lukemisessa on puolestaan olennaista se, mitä lukijalle jää lukemisen jälkeen, eli lukemisen päähuomio on 
lopputuloksessa ja tekstin sisältämässä informaatiossa. Vaikka esteettisessä lukemisessa keskiöön nousevat tunteet ja kokemukset, siinäkin on omanlaisensa tietämisen aspekti: sen avulla voidaan ratkaista ongelmia, rakentaa todellisuutta ja nähdä asioita uudella tavalla (Toivonen 1998, 32-33).

Fiktion lukeminen vaatii aina tulkintaa ja intertekstuaalista lukemista (Hartman 1995). Tulkinta on kokonaisvaltaista ja muistuttaa etenemisessään ihmisten välistä vuorovaikutusta (Linnakylä 2004, 78). Langer (1995, 5-14) näkee fiktion lukemisen näkymöintinä eli maailman rakentamisena, joka perustuu lukijan yksilöllisiin kokemuksiin, ajatuksiin ja tunteisiin. Lukijoiden kokemukset voivat tulkinnan aikana kohdata ja rikastuttaa yksittäisen lukijan ajattelua, itsetuntoa, minäkuvaa ja arvojen muodostusta. Fiktion tulkinta ja merkityksenmuodostus on Langerin (1995, 9-15) mukaan prosessi, jossa teksti vaikuttaa lukijan elämään ja jossa lukijan elämä vaikuttaa tekstin näkymöintiin. Lukiessaan lukija paljastaakin aina jotakin sekä itsestään että lukemastaan tekstistä (Grossman 2001, 417). Arvosen (2002, 39-40) kehittämä, Langerin näkymöintiajatteluun tukeutuva näkymöintistrategia pyrkii edistämään fiktion tulkintaa ryhmätoiminnan avulla. Koska lukijan yksilölliset kokemukset ja tunteet vaikuttavat tekstin ja lukijan väliseen vuorovaikutukseen, fiktio sisältää parhaimmillaan juuri sitä informaatiota, jota lukija tarvitsee. Kun lukeminen tuottaa tällaista lukijan tarvitsemaa materiaalia, tekstillä on myös terapeuttinen tehtävä. (Toivonen 1998, 26.)

Fiktion kertova rakenne on merkityksellinen lapsen ja nuoren kasvun kannalta. Fiktion kertova rakenne saattaa ohjata lapsia suhtautumaan valoisammin elämässä kohtaamiinsa ongelmiin, sillä fiktiota lukiessa voi oppia ymmärtämään, että ongelmista ja vaikeuksista huolimatta tilanteet voivat ratketa onnellisesti. (Mäki \& Arvola 2009, 20-44.) Oman näkökulmansa kertovan rakenteen merkitykseen tarjoavat erilaiset elektroniikkapelit, joista kertova rakenne puuttuu. Nuorten kirjallisuuden ymmärtämistä käsittelevä tutkimus osoittaa, että paljon fiktiota lukeneet kehittävät vaikeillekin tilanteille onnellisen loppuratkaisun vähän lukeneita useammin (Aerila 2010, 178-182). Kirjallisuusterapia korostaa myös perinteisten satujen merkitystä, sillä niiden avulla pienikin lapsi voi ymmärtää ponnistelemisen ja uusien asioiden oppimisen merkityksen (Mäki \& Arvola 2009, 20-44).

Nuortenkirjallisuuden ajatellaan sopivan hyvin nuorten kasvun tukemiseen: nuortenkirjat kuvaavat toisaalta tilanteita, jotka poikkeavat yhtenäismoraalin opetuksesta, toisaalta sosiaalistavat ja ohjaavat nuoria vallitseviin arvoihin (Grünn 2003, 293). Fiktiota lukiessaan nuorella on mahdollisuus testata omaa maailmankuvaansa ja mielikuviaan maailmasta: lukiessa omat käsitykset ja kokemukset ovat koko ajan vuorovaikutuksessa teoksen tapahtumien ja tunnelmien kanssa, ja lukija joutuu kohtaamaan tekstin hänessä herättämät tunteet ja käsittelemään niitä. (McGinley ym. 1997, 5556; Koskela \& Lankinen 2003, 38.) Nuorilla tämä on erityisen tehokasta, koska he 
suhtautuvat lukemiinsa tapahtumiin ja henkilöihin kuin ne olisivat todellisia (Appleyard 1990, 11).

Fiktion etäännyttävää vaikutuksta pidetään tärkeänä kasvun kannalta. Monien nuorten on helpompi käsitellä itselleen vaikeita aiheita, kuten kiusaamista tai suvaitsevaisuutta, asettumalla jonkin kirjallisuuden henkilön asemaan. (Dodson 2000.) Jotta fiktio onnistuisi kasvattavassa tehtävässään, siinä on oltava uskottavia henkilöhahmoja ja tilanteita, joihin nuori pystyy samaistumaan (Boles 2006; Heikkilä-Halttunen 2001, 174). Näyttää siltä, että nuoret pystyvät ymmärtämään haastavaakin kirjallisuutta, mikäli siitä löytyy samaistumisen kohteita (Aerila 2010, 191-195; Airaksinen 1993, 29). Kirjallisuuden, tai esimerkiksi draaman, kautta tapahtuvaa roolin ottamista ja samaistumisen harjoittelemista pidetään tehokkaina tapoina oppia empatiaa sekä lisätä halua auttaa muita (Linnakylä 2004, 46; Solomon 2001, 571). Fiktion ymmärtäminen ja empatian kokeminen ovat hyvin lähellä toisiaan, sillä molemmissa on kyse toisen asemaan asettumisesta (Aerila 2010, 34-37).

Luettavan kirjallisuuden valinnassa on oltava tarkkana, sillä nuori samaistuu mieluiten hahmoon, jolla on hänen mielestään tavoiteltavia ominaisuuksia. Nuortenromaaneissa monet hahmot, joilla on kielteisiä ominaisuuksia, kuvataan aikuisemmiksi ja rohkeammiksi kuin muut. Tämä saattaa innostaa erityisesti poikia eläytymään juuri näihin hahmoihin. (Aerila 2010, 186; Appleyard 1990.) Monilla nuorilla on kielteinen ja väkivaltainen maailmankuva, mikä saattaa kuulua nuoren kehitysvaiheeseen. Brozon (2002, 32-34) mukaan syitä ovat myös vähäinen lukeminen ja runsas elokuvaviihteen seuraaminen: kirjallisuudessa sankarihahmo on pahuuden vastakohta, joka rakentuu itsekurille ja korkealle moraalille, mutta elokuvissa vastaava hahmo hallitsee väkivallalla.

Lahtinen on selvittänyt elämäkertojen ja fiktion lukemisen eroa: jälkimmäisiä tulkitaan inhimillisen kokemuksen ja maailman todenmukaisina kuvauksina, kun taas elämäkertoja luettaessa kommunikatiivinen funktio korostuu ja teksti luetaan tapahtuneiden asioiden kuvauksena. (Lahtinen 2001, 199.) Elämäkerrat tarjoavat lukijoille fiktion tapaan toisen henkilön kokemuksen, mutta elämäkerrassa on kyse valmiiksi tulkitusta näkemyksestä ja merkityksen rakentumisessa painottuu tekijän rooli lukijan roolin sijaan (Lahtinen 2001, 170). Fiktiossa lukijan huomio kiinnittyy esteettisen lukemisen mukaisesti lukukokemukseen ja luetun herättämiin tunteisiin, kun taas elämäkerroissa huomio kohdistuu kirjoittajan elämäntapahtumilleen antamaan merkitykseen. Lahtisen (2001, 199-200) mukaan osa lukijoista lukee myös fiktiota kuin se olisi totta. Tämä ehkäisee lukemiseen liittyvien mielikuvien syntymistä ja kaventaa merkitysten ymmärtämistä.

Fiktion lukeminen edistää opitun syvällistä ymmärtämistä, koska lukija osallistuu tekstin ymmärtämiseen kokonaisvaltaisesti. Voidaankin puhua kaksoistietoisuudesta, jolla tarkoitetaan sitä, että yksilön ymmärtäminen ja oppiminen on tehokkaimmillaan, kun oppimisessa on mukana niin tietoinen kuin tiedostamaton, mielikuvien ja tun- 
teiden, taso. Kirjallisuuskasvatus on yhdistettävissä sekä kokemukselliseen oppimiseen että draamakasvatukseen. Lähellä kaksoistietoisuutta on toiminnallisen oivalluksen käsite, jolla kokemuksellisessa oppimisessa tarkoitetaan eläytyvässä työskentelyssä syntyvää uutta sisäistä näkökulmaa ja ymmärrystä asioihin. Toiminnallisen oivalluksen hetkellä työskentelijä on tietoisesti yhteydessä omaan sisäiseen maailmaansa ja tunnistaa oman subjektiivisen totuutensa uudella tavalla ja uusilla tasoilla. (Kellerman 1992, 87.)

Fiktion käytöstä kasvatuksessa on vähän tutkimukseen perustuvaa tietoa tai pedagogisia sovelluksia, ja kirjallisuuskasvatusta ja eettis-moraalista kasvatusta yhdistetään melko vähän (Maxwell 2006, 335-337). Lisäksi fiktion ymmärtämiseen vaikuttavat monet opettajasta riippumattomat tekijät, kuten oppilaan lukutaito, mielenkiinnon kohteet, kokemusmaailma, empatiakyky sekä kulttuuriset ja sosiaaliset suhteet. Opettajan voi olla vaikea ennakoida, miten oppilaat ymmärtävät tekstejä ja miten he suhtautuvat niihin. (Galda ym. 2000, 367; Maxwell 2006, 339-341.) Ennakkoluuloisuutta kirjallisuuskasvatusta kohtaan saattaa lisätä myös se, että osan lukijoista on vaikeampi kehittää empatiakykyä kirjallisuutta lukemalla kuin toisten (Nussbaum 2011). Kaikki kirjallisuuden herättämät tunteet eivät myöskään ole myötätuntoa. Väkivallasta kertovia tekstejä luettaessa myötätunnosta tai empatiasta voidaan puhua vasta silloin, kun lukija ajattelee uhrien asemaa ja kärsii heidän puolestaan. Vaikeaa voi olla myös todistaa, mistä lukemisen aiheuttamat tunteet johtuvat, sillä jo tietyt sanat voivat herättää lukijoissa suruun tai iloon liittyviä mielleyhtymiä. (Maxwell 2006, 336-338, 344.) Lisäksi eri-ikäiset oppilaat suhtautuvat kirjallisuudessa kuvattuihin ristiriitatilanteisiin eri tavoin: mitä vanhemmasta oppilaasta on kyse, sitä useammin hän suhtautuu puolustellen esimerkiksi teoksissa kuvattuun rasismiin, joka ei kohdistu oman kulttuurin edustajiin (Kruse 2001, 26-32).

Suomessa Toivonen (1998) on kehittänyt kirjallisuuskasvatukseen semioottisen työmenetelmän. Menetelmän lähtökohtana on fiktiivinen teksti, jota lähestytään etukäteen valitun arvon näkökulmasta kolmen erillisen vaiheen kautta. Toivosen menetelmää testanneet tutkimukset (Toivonen 1998; Aerila 2010) osoittavat, että fiktiivistä kirjallisuutta lukemalla on mahdollista vaikuttaa lapsen ja nuoren arvoja koskevaan ajatteluun ja että fiktiivistä kirjallisuutta voidaan käyttää osana koulujen kasvatustehtävää.

\section{Fiktiivisen kirjallisuuden merkitys eri kulttuurien ymmärtämisessä}

Monikulttuurisen lasten- ja nuortenkirjallisuuden lukemisella on tutkitusti positiivisia vaikutuksia erilaisista taustoista tulevien lasten kasvuun. Monikulttuurisen kirjallisuuden lukeminen lisää kulttuuritietoutta, kehittää itsetuntemusta ja edistää kulttuurien välistä ymmärrystä. Omaa kulttuuria positiivisesti kuvaavat lasten- ja nuortenkirjat vaikuttavat myönteisesti erityisesti vähemmistöryhmien lasten itsetuntoon ja saavat hei- 
dät tuntemaan yhteenkuuluvuutta enemmistön kanssa. Enemmistöön kuuluvat lapset puolestaan voivat monikulttuurista kirjallisuutta lukemalla lisätä ymmärrystään erilaisuutta kohtaan, lisätä tietoaan eri kulttuureista ja huomata, että erilaisuudestaan huolimatta ihmisillä on myös paljon samanlaisia ominaisuuksia. (Boles 2006; Iglesia 2013.) Monikulttuuristuvassa koulussa on tärkeää kiinnittää huomiota siihen, että oppilaille luettavaksi annettavat teokset heijastavat oppilaiden erilaisia kulttuuri- ja kansallisuustaustoja (Shioshita 1997).

Fiktiivinen kirjallisuus soveltuu monikulttuurisuuskasvatukseen, sillä monikulttuuriseen kirjallisuuteen eläytymällä lukija voi tutustua erilaisiin yhteiskuntiin ja kulttuureihin sekä niiden rakenteisiin (Seeley 1992, 19). Monikulttuurisuusaiheiset nuortenromaanit antavat sekä tietoa monikulttuurisuudesta että mahdollisuuden eläytyä erilaisiin tilanteisiin (Aerila 2010, 183-186). Myös reader response -teorioiden mukaan fiktiota lukemalla nuoret ymmärtävät, että eri aikojen, paikkojen ja ihmisten välillä on samankaltaisuuksia ja eroja. Näin nuoret oppivat elämästä ja monikulttuurisuudesta. (Purves 1991, 59.) Fiktiota lukemalla voidaan siis edistää suvaitsevaisuutta ja saada lapset ymmärtämään, kuinka erilaiset ihmiset kokevat yleismaailmallisesti samanlaisia tunteita, kuten rakkautta, surua ja lapsellisuutta (Lu 2000). Lisäksi näyttää siltä, että lasten ja nuorten on helpompi omaksua myös monikulttuurisuuteen liittyvää tietoa, kun se esitetään kertomuksena, eikä yksittäisinä faktoina (The role of multicultural literature 2013).

Häggblom (2006) on tutkinut monikulttuurisen kirjallisuuden lukemista suomenruotsalaisessa kielikylpyluokassa. Monikulttuurisuusaiheinen kirjallisuus lisää tietoisuutta kulttuurin ja erilaisuuden merkityksestä ja auttaa suhtautumaan empaattisesti erilaisuuteen ja toisen kulttuurin edustajiin. Pelkkä kirjallisuuden lukeminen ei kuitenkaan riitä, vaan on tärkeää keskustella opettajan johdolla luetun kirjallisuuden pohjalta. Huomattavaa kokeilussa on, että siinä käytetty kirjallisuus ei kuvannut Suomea tai ollut suomalaisten kirjoittamaa ja että aihepiirin vieraus vaikeutti lasten eläytymistä. Aerila (2010) on testannut ennakointikertomuksen kirjoittamista monikulttuurisuusaiheisen opetuskeskustelun tehostajana. Kokeilussa 14-15-vuotiaat oppilaat lukivat katkelmia suomalaisista monikulttuurisuusaiheisista nuortenromaaneista ja pyrkivät kirjoittamalla arvaamaan niiden jatkon. Romaanit oli valittu niin, että niiden henkilöt ja tapahtumaympäristö muistuttivat lukijoita ja heidän maailmaansa läheisesti. Tutkimuksen perusteella voidaan todeta, että fiktioon perustuvien ennakointikertomusten pohjalta saattaa olla mahdollista tehdä päätelmiä kirjoittajan eettis-moraalisesta ja arvoja koskevasta ajattelusta ja asenteista.

Kirjallisuuden valintaan ja käsittelyyn on kiinnitettävä erityistä huomiota, jotta sitä voidaan käyttää kasvattavasti. Monikulttuurisen kirjallisuuden kasvavasta valikoimasta huolimatta monet opettajat eivät tunne teoksia tai ovat epävarmoja niiden soveltu- 
vuudesta kulttuurienväliseen kasvatukseen: Pelkkä kirjallisuuden lukeminen ja sen sisältämien yksityiskohtien kummastelu ei riitä. Jos kiinnitetään huomiota vain eroihin suhteessa omaan kulttuuriin tai kuvatun kulttuurin erikoisiin yksityiskohtiin, kirjallisuuden käyttäminen voi kääntyä itseään vastaan ja pahimmillaan lisätä suvaitsemattomuutta. (Grossman 2001; Short 2009, 2.) Lehman (2011) korostaa opettajien vastuuta monikulttuurisen kirjallisuuden lukemisessa. Erityisen haastavaa tämä on silloin, kun kirjallisuus on oman kokemuksen ja tietämyksen ulkopuolella. Kaikenlaista kirjallisuutta voi lukea, mutta on huolehdittava siitä, että lapsia ohjataan kriittiseen lukemiseen ja väärät tai ennakkoluuloiset käsitykset oiotaan.

Monikulttuurista lasten- ja nuortenkirjallisuutta on märitelty monin tavoin. Kasvatuksen kontekstissa monikulttuurisella kirjallisuudella tarkoitetaan vähemmistöryhmien kirjallisuutta, jota luetaan luokissa erilaisuuden kunnioittamiseksi ja hyväksymiseksi (Sims Bishop 2007, 14). Tämäntyyppinen kirjallisuus koskettaa kaikkia rodusta, luokasta tai sukupuolesta riippumatta. Pohjimmaltaan siinä kuvataan yleisiä ihmisyyteen kuuluvia taisteluita ja vaikeuksia (Gopalakrishnan 2011, 4-5, 24). Osa monikulttuurisen lasten- ja nuortenkirjallisuuden määritelmistä korostaa kirjailijan autenttista suhdetta teoksessa kuvattuun kulttuuriin (Gopalakrishnan 2011, 25). Sims (1982) on verrannut toisiinsa amerikanafrikkalaisten ja muiden kuin amerikanafrikkalaisten kirjoittamia, amerikanafrikkalaisia kuvaavia romaaneita. Hän on todennut, että teoksissa painotetaan erilaisia asioita ja että muiden kuin amerikanafrikkalaisten kirjoittamat teokset ovat usein puutteellisia. Short (2009) korostaa kansallista näkökulmaa: kirjallisuudella on oltava riittävästi yhtymäkohtia lukijan omaan elämään. Jos monikulttuurinen lasten- ja nuortenkirjallisuus määritellään edellä kuvatulla tavalla, voidaan sanoa, ettei Suomessa ole ilmestynyt yhtään monikulttuurista nuortenkirjaa. Yksikään suomalaisista nuortenkirjailijoista ei edusta autenttisesti kuvaamaansa vierasta kulttuuria. (Aerila \& Kokkola 2013.)

Johnson Higgins (2010) on kehittänyt kasvattajille välineen sekä monikulttuurisen lasten- ja nuortenkirjallisuuden valintaan että sen arviointiin. Hänen mukaansa käsitettä monikulttuurinen lasten- ja nuortenkirjallisuus käytettiin aiemmin kuvaamaan vain teoksia, joissa vähemmistöjä kuvattiin positiiviseen sävyyn, kun nykyään tavoitteena on realistisen kuvan antaminen eri kulttuureista. Johnson Higginsin (2010, 3-5) kriteeristö perustuu lasten- ja nuortenkirjojen sisältämiin stereotypioihin ja kielteisiin mielikuviin eri kulttuureista sekä teosten kirjalliseen laatuun. Hänen mukaansa huomiota on kiinnitettävä teosten henkilöhahmojen dialogiin, jonka on edustettava autenttisesti myös vähemmistöryhmien suullista traditiota, ja henkilöhahmojen asemaan kerronnassa niin, että vähemmistöhahmot ovat yhdenvertaisia enemmistön kanssa ja toimivat itse omien ryhmiensä johtajina. Lisäksi hän $(2010,5)$ pitää yhtenä monikulttuurisen kirjallisuuden laadun kriteerinä teoksen ilmestymisvuotta. Hänen mukaansa esimer- 
kiksi kaikki vähemmistöjä käsittelevät kirjat, jotka ilmestyivät Yhdysvalloissa 1960luvun loppuun mennessä, ovat valtaväestön edustajien kirjoittamia ja heijastelevat valkoisten keskiluokkaista maailmaa.

Vastaavia ohjeita monikulttuuristen lasten- ja nuortenkirjojen arviointiin on kehitetty myös muita. Shioshitan (1997) ohjeisto perustuu Newlingin kokoamaan listaukseen, ja siinä mainitaan teosten henkilöhahmoihin liitetyt lempinimet, jotka voidaan kokea loukkaavina. Lisäksi hän kehottaa valitsemaan teoksia, jotka kiinnostavat nuoria lukijoita muutenkin. Myös Iglesia (2013) korostaa, että monikulttuuristen kirjojen tulee olla lapsille positiivisia lukukokemuksia ja lasten tulee voida lukea monikulttuurista kirjallisuutta pohtimatta teoksen monikulttuurisia arvoja. Kirjojen soveltuvuuden arviointi on opettajan vastuulla. Monikulttuuristen lasten- ja nuortenkirjojen arviointia erilaisten listojen pohjalta voidaan pitää sensuurina, mutta sensuuria tärkeämpää on koulussa opettajan vastuu oppilaan suojaamisesta loukkaavilta teksteiltä (Shioshita 1997).

Gopalakrishnan (2011,29-33) on luokitellut monikulttuurisia lasten- ja nuortenkirjoja Sims Bishopin (1982) monikulttuurisen kirjallisuuden määritelmien pohjalta. Sulatusuunikirjat kuvaavat kulttuurien moninaisuutta ja kokemuksia kulttuurisesta moninaisuudesta. Ne osoittavat, että kaikki ihmiset ovat pohjimmiltaan samanlaisia eikä ihmisiä voi syrjiä etnisyyden tai rodun perusteella. Sosiaalista tiedostamista edustavat kirjat esittelevät yhden kulttuurin ja siihen liittyvän yksilöllisen kokemuksen. Näiden teosten tarkoituksena on saada ihmiset tiedostamaan tietyn kulttuurisen vähemmistön oloista. Sosiaalista tiedostamista kuvaavat kirjat saavat kiinnittämään huomiota monikulttuurisuuteen liittyviin kysymyksiin, mutta voivat olla ulkopuolisen näkökulmasta esitettyjä eivätkä pyri ratkaisemaan kuvattuja ongelmia tarinan aikana. Kulttuurista tiedostamista edustavat teokset kuvaavat kulttuuriin liittyviä traditioita tai kieleen ja etnisyyteen liittyviä kokemuksia autenttisella äänellä. Ne kertovat todellisista kulttuurisista ristiriidoista ja pakottavat keskustelemaan kriittisesti esimerkiksi yhteiskunnassa vallitsevista valtasuhteista. Gopalakrishnanin (2011) mukaan tämän ryhmän kirjat ovat monikulttuurisimpia, sillä ne koskevat vain tiettyjä ryhmiä ja antavat muille mahdollisuuden ymmärtää heidän maailmaansa. Opetuksessa kuitenkin käytetään tavallisimmin sulatusuunikirjoja, sillä ne soveltuvat vaivattomasti kaikille ryhmille eivätkä vaadi opettajalta ennakkovalmisteluja (Gopalakrishnan 2010, 29-33).

Aerila (2010) on tutkinut Suomessa ilmestyneitä nuortenromaaneja, joissa on monikulttuurisuusaihelma ja joissa kuvataan suomalaisia ja Suomea. Huomionarvoista on, että Suomessa monikulttuurinen lasten- ja nuortenkirjallisuus on yhä valtaväestön edustajien kirjoittamia, ja teosten näkökulma on pääasiassa keskiluokkainen. Suomalaisten nuortenromaanien tiedot ja tilanteet vastaavat todellisuutta, mutta tieto on kapea-alaista ja stereotyyppistä. Vaikka teosten maailmankuva on kapea, niissä kuva- 
taan maahanmuuttajia monipuolisemmin kuin perusopetuksen monikulttuurisuuskasvatuksessa yleensä. Pantzarin $(2009,105)$ mukaan koulujen kasvatuskäytännöissä maahanmuuttajia kuvataan pääasiassa kielen, etnisyyden ja kulttuurin kannalta. Nuortenromaaneissa maahanmuuttajiin liitetään näiden ominaisuuksien lisäksi samanlaisuutta kuvaavia ominaisuuksia, kuten seurustelu, ulkonäkö- ja raha-asiat. $\mathrm{Ne}$ saavat lukijan kiinnittämään huomiota eri kansallisuuksia edustavien nuorten yhteisiin piirteisiin. (Aerila 2010, 183-186.)

Nuortenromaanit edustavat usein stereotypiaa tietystä kulttuurista tai kansasta. Niistä keskusteleminen on tärkeä osa monikulttuurisuuskasvatusta, sillä eri kansallisuuksiin liitetyt stereotypiat ovat usein varsin pysyviä ja saattavat muuttua vaarallisiksi, jos ne jävät käsittelemättä (Boles 2006; Kaikkonen 2004). Monissa suomalaisissa nuortenromaaneissa stereotypioita pyritään rikkomaan paljastamalla henkilöhahmoista ominaisuuksia, jotka eivät kuulu stereotyyppiseen käsitykseen, tai kuvaamalla toisilleen vastakkaisia henkilöhahmoja. Stereotyyppi-käsitteen rinnalla voi käyttää prototyypin käsitettä, jolla tarkoitetaan monissa oppiaineissa oppimisen lähtökohtana olevaa mallia. Hyödyllinen voisi olla myös sarjakuvista tuttu pelkistämisen käsite. Sillä viitataan sarjakuvissa sellaisiin yksinkertaistuksiin, joiden tarkoituksena on helpottaa kerronnan seuraamista. (Stereotyypeistä suomalaisessa nuortenkirjallisuudessa myös Julkunen 1997; sarjakuvista Herkman 1998.) Suomalaisissa nuortenkirjoissa ongelmallisimpia ovat venäläisten henkilöhahmojen stereotyypit, sillä venäläisiin liitetään useimmiten kielteisiä stereotypioita eikä niitä juurikaan rikota tai haasteta vastakkainasetteluilla. Venäläisistä kertova nuortenromaani saattaakin pahimmillaan vahvistaa kielteisiä stereotypioita. (Aerila 2010, 118-123.)

Pelkkä monikulttuurisen kirjallisuuden sijoittaminen luokkaan tai kirjallisuuden vapaavalintainen lukeminen ei riitä, kun kirjallisuutta käytetään osana kasvatusta. Tutkimukset osoittavat, että monikulttuurinen kirjallisuus ja siihen yhdistetyt oppilaita aktivoivat menetelmät parantavat sekä lukemisen tuloksia että oppilaiden asenteita eri kulttuureja kohtaan. (Norton 2009, 2.) Opettajan toiminnalla ja opetuskeskustelun onnistumisella on merkittävä osuus monikulttuurisessa kirjallisuuskasvatuksessa. Tappan (1998, 135-150) on yhdistänyt kirjallisuuskasvatukseen Lev Vygostkyn lähikehityksen vyöhykkeen käsitteen ja todennut, että kokeneemman lukijan ohjauksessa on mahdollista kehittyä eettis-moraalisessa ajattelussa. Opettaja voi siis antaa kirjallisuuskeskusteluissa oppilaille mallin myönteisestä kulttuurienvälisestä ajattelusta. Tämä vaatii opettajalta hyvää lukutaitoa, nuortenkirjojen tuntemusta, tietoa erilaisista kulttuureista ja maahanmuuttajuudesta sekä ennakkoluulotonta asennetta erilaisuutta kohtaan. (Aerila 2010, 190-195.)

Dongin (2005) kokeilussa opettajat lukivat lukupiireissä erilaisia monikulttuurisuusaiheisia tekstejä ja keskustelivat niistä. Lukupiirijakson päätyttyä opettajat tekivät 
luokissaan erilaisia monikulttuurisen kirjallisuuden lukemiseen liittyviä opetuskokeiluja. Opetuskokeilut osoittavat, että jo pienetkin oppilaat pystyvät keskustelemaan rasismiin, kulttuuriin ja yhteiskunnalliseen oikeudenmukaisuuteen liittyvistä kysymyksistä. Erityisen hyvänä työmenetelmänä pidetään teoksen kuvaamaa kulttuuria edustavan oppilaan käyttämistä ns. sisäpiirin asiantuntijana. Tämä tarjosi opettajalle mahdollisuuden tutustua oppilaisiin ja oppia heidän kulttuureistaan. Myös oppilaille oli tärkeää saada kertoa omasta kulttuuristaan ja kokea arvostusta luokassa. Positiivisena koettiin myös kirjallisuuskeskusteluiden muuttuminen enemmän arkikeskusteluita muistuttaviksi yleisiksi monikulttuurisuutta koskeviksi keskusteluiksi.

Myös Louie (2006, 439-440) korostaa keskustelun ja muun oppilaita aktivoivan toiminnan merkitystä, kun monikulttuurista kirjallisuutta käytetään opetuksessa. Sekä keskusteluissa että luetusta tehtävissä muissa tehtävissä on pyrittävä antamaan oppilaille mahdollisuus eläytyä teosten henkilöhahmojen tilanteisiin, ajatuksiin, ristiriitojen ratkaisumalleihin ja sisäisiin ristiriitoihin. Näitä eläytymisharjoituksia voidaan käyttää sekä pohjustuksena opetuskeskustelulle että osana keskustelun jälkeistä itsereflektiota. Oppilaiden monikulttuurinen ymmärrys kasvaa parhaiten, kun he pystyvät yhdistämään henkilöhahmojen kokemukset omaan elämäänsä ja luomaan näin henkilökohtaisen suhteen teoksen henkilöihin ja näiden kokemuksiin. Opettaja voi tukea tätä samaistumista esimerkiksi listaamalla teoksen henkilöiden kohtaamia konflikteja ja näihin konflikteihin liittyviä ratkaisumahdollisuuksia sekä selittämällä syitä henkilöiden tekemiin ratkaisuihin. Apuna voi käyttää myös saman tekstin eri versioiden vertaamista.

\section{Monikulttuurisuuskasvatus ja fiktiivinen kirjallisuus}

Monikulttuurista lasten- ja nuortenkirjallisuutta voidaan käyttää kaikissa perinteisissä monikulttuurisuuskasvatuksen muodoissa. Banksin ja McGee Banksin (2001) määritelmässä matalimman tason monikulttuurisuuskasvatusta kutsutaan turisti-, ruokatai juhlanäkökulmaksi. Siinä monikulttuurista kirjallisuutta esitellään juhlapäivinä. Kyse on vieraaseen kulttuuriin tutustumisesta, eikä kirjallisuutta arvioida lainkaan sen autenttisuuden tai sisältöjen perusteella. Toiseksi matalimman tason monikulttuurisuuskasvatuksessa sisältöjä lisätään opetukseen ilman arviointia. Tällöin voidaan lukea erimaalaisia kansansatuja ja tuoda luokkaan eri kulttuurien edustajia kertomaan tavoistaan. Fiktiota käytetään esimerkiksi taustamateriaalina ennen vierailukäyntiä. Tämäkin voidaan nähdä vierailuna vieraaseen kulttuuriin. Kolmannella monikulttuurisuuskasvatuksen tasolla tavoitteena on saada opiskelijat tarkastelemaan aihetta, käsitteitä ja kirjallisuutta etnisyyden ja kulttuurin kannalta. Oppilaille tarjotaan fiktiivistä kirjallisuutta, joka ei vastaa enemmistön näkemyksiä. Kirjallisuus antaa mahdollisuuden lukea samoista tapahtumista eri näkökulmista ja asettua itselle vieraan henkilön asemaan. 
Lisäksi se luo mahdollisuuksia monipuoliseen keskusteluun. Neljännellä tasolla päämäränä on saada oppilaat toimimaan oikeudenmukaisemman ja tasa-arvoisemman yhteiskunnan puolesta. Fiktion kohdalla tämä tarkoittaa historiallisia tapahtumia kuvaavien teosten lukemista ja niiden vertaamista nykypäivän tapahtumiin ja esimerkiksi tiedotusvälineiden teksteihin. Tavoitteena on liittää kirjallisuuden tapahtumat konkreettisesti todellisuuteen. (Gopalakrishnan 2011, 26-28.) Boles (2006) mainitsee esimerkkinä oppilaiden konkreettisesta toiminnasta kirjeet poliittisille päättäjille ja erään yhdysvaltalaisen koulun ruokalan istumajärjestyksen muuttamisen niin, että samaa kulttuuritaustaa edustavat nuoret eivät enää istuneet omina ryhminään.

Monikulttuurisuuskasvatukseen soveltuvia kirjallisuuspohjaisia, järjestelmällisiä pedagogisia malleja ja kokeiluja on useita, mutta Nortonin (2009) viisiportainen menetelmä on yksi järjestelmällisimmistä. Lisäksi esimerkiksi Short (2009) ja Leming (2000) ovat testanneet kuvakirjojen käyttöä eettisen ja monikulttuurisen kasvatuksen välineinä ja Louie (2006) on kehittänyt menetelmän, jossa saman tarinan eri versioita vertaamalla opitaan ymmärtämään kulttuurin vaikutusta kirjallisuuteen ja yksilöiden elämään.

Nortonin (2009) menetelmässä ensimmäisen portaan tavoitteena on saada opiskelijat ymmärtämään ja arvostamaan kulttuuria kielen ja elämänfilosofian välittäjänä. Kirjallisuutena käytetään vanhoja myyttejä, legendoja ja kansantarinoita, joita vertaillaan keskenään. Toisella portaalla rajataan ensimmäisessä vaiheessa käytetty materiaali koskemaan jotakin tiettyä kulttuurin aluetta. Tavoitteena on verrata suppeamman alueen tarinoita ensimmäisen vaiheen tarinoihin ja pohtia, mitä eroa näillä on. Kolmannella portaalla luetaan ei-fiktiivistä kirjallisuutta, eli elämäkertoja, sekä jonkin tietyn ryhmän vapaamuotoista kirjallisuutta. Tavoitteena on kirjallisuuden, keskusteluiden ja tehtävien avulla kannustaa ymmärtämään tietyn kulttuurin edustajien historiaa. Kolmannen vaiheen lopuksi tarkoituksena on löytää tarkasteltavana olevaan kulttuuriin ja kansaan vaikuttaneet historialliset tapahtumat. Neljännellä portaalla keskitytään nykypäivän kirjallisuuteen ja luetaan historiallisia romaaneja tarkasteltavana olevasta kulttuurista. Kirjallisuus, keskustelut ja tehtävät kannustavat käyttämään taustatietoa, joka on saavutettu aiemman lukemisen ja keskustelun aikana, ja arvioimaan kirjallisuuden autenttisuutta, uskottavuutta ja luotettavuutta. Suomessa ongelmaksi muodostuu opetusmateriaali: yhdestäkään vähemmistöryhmästä ei ole saatavilla edellä kuvatun kaltaista, korkeatasoista kirjallisuutta (Aerila, Soininen \& Merisuo-Storm 2013).

Suoraan suomalaiseen kouluun sovellettavissa on Louien (2006) menetelmä, jonka pohjana käytetään klassikkosatuja ja joista myös Suomessa on saatavilla useita versioita. Artikkelissaan "Guiding principles for teaching multicultural literature" Louie kuvaa opetuskokeilua, jossa alakoulun oppilaat tutustuivat viiteen eri versioon 
Mulan-sadusta. Sadun käsittelyn eteneminen perustui kulttuurienvälisen ymmärryksen tarkasteluun kolmen kategorian kautta: Kriittisen ymmärtämisen kategoria tarkoittaa tekstin lähilukemista ja tekstin sisältämien arvojen ja autenttisuuden arviointia. Empaattisen ymmärtämisen vaiheessa oppilaat eläytyvät henkilöhahmojen tilanteisiin ja tunteisiin ja arvioivat henkilöhahmojen tunteiden ja toimintojen merkitystä. Käsitteellisen ymmärtämisen vaiheessa oppilaat siirtävät luetun synnyttämät ajatukset yleisemmälle tasolle ja arvioivat kulttuurin merkitystä ihmisten ajatuksiin, tunteisiin ja toimintaan. (Louie 2006, 441-447.)

\section{Ajatuksia perusopetuksesta ja fiktiivisestä kirjallisuudesta}

Monikulttuurisuuskasvatus edellyttää henkilökohtaisen kokemuksen syntymistä suhteessa kirjallisuuteen. Monissa luokissa kirjallisuudenopetus keskittyy kirjallisuuden käsitteiden opiskeluun eikä henkilökohtaista suhdetta kirjallisuuteen pääse syntymään. Henkilökohtaisen suhteen syntymiseen vaikuttaa myös oppilaan aikaisempi kulttuureihin liittyvä tietämys: Liian vähäinen tietämys vaikeuttaa teokseen eläytymistä, mutta liiallinen opettajan tarjoama informaatio voi estää henkilökohtaisen suhteen syntymisen kokonaan. Saattaakin olla tehokkaampaa, että opettaja tarjoaa oppilaille faktatietojen rinnalla myös muuta materiaalia tutustuttavana olevasta kulttuurista. Tällaista materiaalia voivat olla esimerkiksi kulttuuriin liittyvät kuvat, videot, äänet ja maut. Parhaimmillaan monikulttuuriseen kirjallisuuteen tutustuminen tarjoaa oppilaalle mahdollisuuden samaistua useisiin kulttuureihin ja mahdollisuuden oppia omasta kulttuuritaustasta ymmärtämällä, miten muut näkevät sen. (Dietrich \& Ralph 1995, 2-4.)

Yhä useampi opettaja joutuu työssään kohtaamaan oppilaita, joiden kulttuuritausta ja kieli eivät ole samoja kuin opettajan, ja on etsittävä keinoja lisätä opettajien kulttuurienvälistä ymmärrystä. Monikulttuurinen kirjallisuus tarjoaa tähän välineitä. Dong (2005, 380-381) on tutkinut opettajien suhdetta monikulttuurisen kirjallisuuden käyttämiseen opetuksessa. Opettajat valitsevat mieluiten omaa kulttuuriaan kuvaavaa, kanonisoitua kirjallisuutta, sillä muunlaisen kirjallisuuden lukeminen merkitsee usein opettajan ja oppilaan roolin muuttumista niin, että oppilas saattaa olla asiantuntijan roolissa luokassa. Lisäksi kirjallisuuden käyttäminen monikulttuurisuuskasvatukseen vaatii uudenlaisten opetusmenetelmien haltuunottoa.

Dongin (2005, 367-381) mukaan opettajat ovat myös epävarmoja sen suhteen, kuinka kunnioittavasti ja kypsästi oppilaat osaavat käsitellä eri kulttuureihin liittyviä kysymyksiä. Monikulttuurisuuskasvatuksen näkökulmasta opettajien tulisi lisätä kulttuuritietämystään sekä kehittää herkkyyttään ja pedagogisia taitojaan voidakseen vahvistaa lasten kulttuurista tietämystä ja kykyä ymmärtää erilaisia näkökulmia ja kulttuurisia eroja (Dong 2005, 367). Kirjallisuuskasvatukseen suunnattuja pedagogisia teoksia 
ei ole juuri suomennettu eikä opettajilla ole valmiuksia käyttää kirjallisuutta osana eettis-moraalista kasvatusta. Lisäksi tarvittaisiin tutkimusta siitä, miten opettajien oma kulttuuritausta, asenteet ja eläytyminen kirjallisuuteen vaikuttavat oppilaiden kirjallisuuden ymmärtämiseen (Dietrich \& Ralph 1995, 4). Fiktion monipuolisempi ja laajeneva käyttö tulisi ottaa huomioon myös koulujen kirjamäärärahoissa, koulukirjastojen määrän lisäämisessä ja opetussuunnitelman tasolla. Myös tutkimuksen kautta opetusmenetelmien kehittämistä ja siirtämistä käytännön tasolle olisi pyrittävä edistämään.

Monikulttuurisen kirjallisuuden käyttäminen opetuksessa sisältää monia haasteita: Korkealaatuista, monikulttuurista kirjallisuutta ei ole kansainvälisestikään riittävästi tarjolla. Soveltuvan monikulttuurisen kirjallisuuden arvioiminen ja etsiminen vaatii opettajilta suurta panostusta, ja opettajat pelkäävät loukkaavansa oppilaita valitsemalla luettavaksi sopimatonta kirjallisuutta. Lisäksi monikulttuurista kirjallisuutta on luettava oppitunneilla runsaasti, sillä yksittäisten teosten lukeminen ei lisää kulttuurienvälistä tietämystä riittävästi. Saattaisikin olla tarpeen kehittää järjestelmä, jossa tietyn kulttuurin edustajat lukisivat ja arvioisivat kirjallisuutta, ja nämä arvioinnit olisivat opettajien käytössä. (Mendoza \& Reese 2001, 1-32.) Suomalainen lasten- ja nuortenkirjallisuus käsittelee monia nuoria koskettavia, vaikeitakin aiheita. Maahanmuuttajataustaisia henkilöitä olisi kuitenkin kannustettava kertomaan autenttisia tarinoita suomalaisen yhteiskunnan monikulttuurisuudesta.

Jotta fiktiota voitaisiin nykyistä tehokkaammin yhdistää perusopetuksen aihekokonaisuuksiin ja kirjallisuuskasvatukseen, sitä tulisi lukea muidenkin oppiaineiden kuin äidinkielen ja kirjallisuuden tunneilla. Nuortenromaaneja tulisikin käyttää uskonnon, historian ja yhteiskuntaopin, terveystiedon ja maantiedon tunneilla, jolloin monikulttuurisuuskasvatuksen sisällöt olisivat ehkä luontevammin liitettävissä muuhun opetukseen. Lisäksi nuortenromaanin lukeminen jonkin muun oppiaineen kuin äidinkielen ja kirjallisuuden tunnilla voi auttaa erityisesti poikia irrottautumaan lukemiseen liittyvistä kielteisistä asenteista (Brozo 2002).

Jo pelkän monikulttuurisen kirjallisuuden haltuunotto vaatii opettajalta perehtyneisyyttä kirjallisuuteen, nuoriin ja kansoihin sekä niiden kulttuureihin ja historiaan. Fiktion käyttäminen kirjallisuuskasvatuksessa vaatii usean vastaavan aihepiirin hallintaa sekä opetusmenetelmien ja kirjallisuuteen liittyvien tietojen jatkuvaa päivittämistä. Yksittäiselle opettajalle työmäärästä ja sen haasteellisuudesta voi muodostua este kirjallisuuden käyttämiselle. Kirjallisuuskasvatuksen mahdollisuuksia hyödyntävää opettajaa olisikin pyrittävä tukemaan mahdollisimman tehokkaasti. Monissa maissa, erityisesti Yhdysvalloissa, on useita, kaikkien vapaasti käytössä olevia verkkomateriaaleja, jotka sisältävät valmiita opetuskokonaisuuksia, opetusmenetelmien kuvauksia ja kirjallisuuslistoja arviointeineen, ikäsuosituksineen ja sisältökuvauksineen. Vastaavantyyppinen toiminta puuttuu Suomesta vielä kokonaan. 


\section{Lähteet}

AERILA, JULI-ANNA 20IO: Fiktiivisen kirjallisuuden maailmasta monikulttuuriseen Suomeen. Ennakointikertomus kirjallisuudenopetuksen ja monikulttuurisuuskasvatuksen välineenä. Turun yliopiston julkaisuja C: 297. Turku: Turun yliopisto.

AERILA, JULI-ANNA \& LYDIA KOKKOLA 20I3: Multicultural Literature and the Use of Literature in Multicultural Education in Finland. Bookbird-journal 15 (2), 39-50.

AERILA, JULi- ANNA, MARJAANA SOININEN \& TUULA MERISUO-STORM 2OI3: Monikulttuurinen lasten- ja nuortenkirjallisuus opetuskontekstissa. Hyväksytty julkaistavaksi Kasvatus-lehdessä syyskuussa 2013.

APPLEYARD, JOHN I990: Becoming a Reader. The Experience of Fiction from Childhood to Adulthood. Cambrigde: Cambridge University Press.

ARVONEn, JAANA 2002: Toiminta lukemisen tukena. Näkymöintistrategia toisluokkalaisten kirjallisuuden opetuksessa. Turun yliopiston julkaisuja C:182. Turku: Turun yliopisto. BOLES, MARIA 2006: The Effects of Multicultural Literature in the Classroom. Open access senior honors thesis. Teacher Education. <http://www.commons.emich.edu/ honors/62> (22.3.2013)

Brozo, wilhelm 2002: To Be a Boy to Be a Reader. Engaging Teen and Preteen Boys in Active Literacy. Knoxville, Tennesee: The University of Tennesee.

Dietrich, DEBORAH \& RALPh, KaTHLEen I995: Crossing Borders. Multicultural Literature in the Classroom. The Journal of Educational Issue of Language Minority Students $15,1-8$.

Dodson, Michael 2000: Social Ethics and Political Morality: Using Tom and Huck to Develop Moral Reasoning. <http://www.indiana.edu/“^eric_rec/bks/at13ex.html> (21.4.2000)

DONG, YU REN 2005: Bridging the Cultural Gap by Teaching Multicultural Literature. The Educational Forum vol. 69, 367-382.

GALDA, LEE, GWYNNE ASH \& BERNICE CULLINAN 2000: Children's Literature. Handbook of Reading Research. Vol. 3. Ed. M. L. Kamil, P. B. Mosenthal, P. D. Pearson \& R. Barr. New Jersey: Lawrence Erlbaum Associates.

gopalakrishnan, AMBiKa $20 \mathrm{II}$ : Multicultural Children's Literature. A Critical Issues Approach. Los Angeles: California State University.

grossman, PAM 200I: Research on the Teaching of Literature: Finding a Place. Handbook of Research on Teaching. 4. painos. Ed. V. Richardson. Washington D.C: American Educational Research Association.

GRÜNN, KIRSI 2003: Uusin nuortenkirjallisuus. Pieni suuri maailma. Suomalaisen Lasten- ja nuortenkirjallisuuden historia. Toim. L. Huhtala, K. Grunn, I. Loivamaa \& M. Laukka. Helsinki: Tammi, 285-295.

HARTMAN, DOUgLas I 995: Eight Readers Reading. The Intertextual Links of Proficient 
Readers Reading Multiple Passages. Reading Research Quarterly 30 (3), 520-561.

HeIKKIlä-haltTUnEN, PÄIVI 200 I: Nuortenkirjallisuuden teemoja ja virtauksia. Kirjaseikkailu. Lasten- ja nuortenkirjallisuuden opas. Toim. T. Korolainen. Helsinki: Tammi, 219-237.

HeRKMAN, JUHA I998: Sarjakuvan kieli ja mieli. Tampere: Vastapaino.

Higgins Johnson, Jennifer 20io: Multicultural Children's Literature. Creating and Applying an Evaluation Tool in Response to the Needs of Urban Educators. Johns Hopkins University. <http://www.education.jhu.edu/newhorizons/strategies/topics/ multicultural-education/multicultural-childrens-literature/index.html> (21.6.2012) häGgblom, Charlotta 2006: Young EFL-Pupils Reading Multicultural Children's Fiction. An Ethnographic Case Study in a Swedish Language Primary School in Finland. Turku: Åbo Akademis Förlag.

IGLESIA, MICHELE DE LA 20I3: Multicultural Literature for Children. <http://www.ipl. org/div/pf/entry/48493> (7.2.2013)

JULKUNEN,MARJA-LIISA I 997: Tiekirjallisuuteen. Onthewaytoliterature.Joensuu:Joensuun yliopiston kasvatustieteiden tiedekunnan tutkimuksia 65.

KAIKKONEN, PAULI 2004: Vierauden keskellä. Vierauden, monikulttuurisunden ja kulttuuurienvälisen kasvatuksen aineksia. Jyväskylä: Jyväskylän opettajankoulutuslaitos. Kellernan, Peter felix 1992: Focus on Psychodrama. The Therapeutic of Psychodrama. Focus on psychodrama. Lontoo: Jessica Kingsley Publishers.

KOSKELA, LASSE \& PASI LANKINEN 2003: Opas kaunokirjallisuuden lukemiseen. Helsinki: SKS.

KRUSE, M. 200I: Escaping Ethnic Encapsulation. The Role of Multicultural Children's Literature. The Delta Gamma bulletin 67 (2), 26-32.

LAHTINEN, ANNA-MAIJA 200I: Kertovat tekstit opiskelijoiden kokemina ja tulkitsemina sosiaali- ja terveysalan ammatillisessa koulutuksessa. Helsinki: Helsingin yliopiston opettajankoulutuslaitos.

Lammenranta, markus 1989: Kirjallisuus ja tieto. Kirjallisunden filosofiad. Toim. A. Haapala, E. Haapala, A. Kinnunen \& M. Lammenranta. Helsinki: Valtion painatuskeskus, 191-205.

LANGER, JUDITH I995: Envisioning Literature. Literary Understanding and Literary Instruction. NewYork \& London: IRA, Teacher's College Press.

Lappalainen, Hannu-Pekka 200I: Perusopetuksen äidinkielen ja kirjallisuuden oppimistulosten kansallinenarviointi 9. vuosiluokalla 2001. Oppimistulosten arviointi 6/2001. Helsinki: Opetushallitus.

LEHMAN, BARBARA 20I I: Reading Globally: The Reader's Responsibility in Literary Transactions. Bridges to Understanding. Envisioning the World Trough Children's Books. Ed. L. M. Pavonetti Lanham: Scarecrow Press. 
LEMING, JOHn 2000: Tell Me a Story. An Evaluation of a Literature-Based Character Education Programme. Journal of Moral Education 29 (4), 413-427.

LINNA, HeLENA I999: Lukuonni. Kirjallisuuden opetus ala-asteella. Helsinki: WSOY. LINNAKYLÄ, PIRJO 2004: Miten hyvin suomalaisnuoret lukevat erilaisia tekstejä? Tulevaisuuden lukijat. Suomalaisnuorten lukijaprofileja. Toim. P. Linnakylä, S. Sulkunen ja I. Arffman. PISA 2000. Jyväskylä: Jyväskylän yliopiston Koulutuksen tutkimuslaitos. LOUIE, BELINDA 2006: Guiding Principles for Teaching Multicultural Literature. The Reading Teacher 59 (5), 438-448.

LU, MEI-YU 2000: Multicultural Children's Literature in the Elementary Classroom. Eric Digest. <http://www.ed.gov./darabases/ERC_Digests/ed423552.html> (21.4.2000) MAXWELl, BRUCE 2006: Naturalized Compassion. A Critique of Nussbaum on Literature as Education for Compassionate Citizenship. Journal of Moral Education 35 (5), 335-352.

MCGINLEY, WILLIAM, GEORGE KAMBARELIS, TIMOTHY MAHONEY, DAVID MADIGAN, WILLIAM RYBICKI \& JOHN OLIVER I997: Visioning Reading and Teaching Literature Through the Lens of Narrative Story. Reading Across Cultures. Ed. Rogers, T. \& Soter, A. New York: Teacher's College Press.

MENDOZA, JEAN \& REESE, DEBBIE 200I: Examining multicultural picture books for early childhood classroom. Possibilities and pitfalls. Early Childhood Research \& Practice $3(2), 1-32$.

MÄKI, SILJA \& PIRJO ARVOLA 2009: Lapsi tarvitsee juuret voidakseen kasvaa. Tarina tukee lasta. Opas lasten ja nuorten kirjallisuusterapiaan 2. Toim. S. Mäki \& P. Arvola. Helsinki: Duodecim.

NORTON, SHEILA 2009: Multicultural Children's Literature: Through the Eyes of Many Children. Upper saddle River, NJ: Pearson Education.

nussbaum, martha. c. 20 I I: Creating Capabilities. The Human Development Approach. Cambridge, Mass.: Harvard University Press.

PAHKINEN, TUULA 2002: Lukeminen elämässä selviytymisvälineenä. Lukuhaastetta koko elämä. Toim. M. Inovaara \& A. Malmio. Äidinkielen opettajain liiton vuosikirja XLVI. Helsinki: ÄOL, 7-14.

PANTZAR, TUULA 2009: Erilaisuuden ja vierauden ymmärtämisen edistäminen kulttuurienvälisen kasvatuksen tavoitteena. Kielikasvatus, opettajuus ja monikulttuurinen toimijuus. Pauli Kaikkosen juhlakirja. Toim. R. Jaatinen, V. Kohonen \& P. Moilanen. Opetus-, kasvatus- ja koulutusalojen säätiön julkaisuja. Helsinki: ORKA, 95-107. PURVES, ALAN I 99I: The School Subject Literature. Handbook of Research of Teaching English Language Arts. Ed. J. Flood, J. M. Jensen, D. Lapp \& J. R. Squire. New York: Macmillan. 
THE ROLE OF MULTiCULTURAL LITERATURE 2013: < http://www.eduplace.com/rdg/res/ literacy> (7.2.2013)

rosenblatt, Louise 1978: The Reader, the Text, the Poem. Transactional Theory of Literary Work. Carbondale \& Edwardville: Southern Illinois University Press.

RÄSÄNEN, RAULI 2002: Interkulttuurisen pedagogiikan olemusta etsimässä. Interkulttuurinen opettajankoulutus. Utopiasta todellisuudeksi toimintatutkimuksen avulla. Interkulttuurisen pedagogiikan olemusta etsimässä. Toim. R. Räsänen, K. Jokikokko, M.-L. Järvelä. \& T. Lamminmäki-Kärkkäinen. Oulu: Oulun yliopisto. <http://herkules.oulu.fi/isbn9514268075/isbn9514268075.pdf> (27.8.2012) SEELEY, JOHN 1992: Teaching Culture. Lincolnwood: National Textbook Company. SHioshita, JOY I997: Beyond Good Intentions. Selecting Multicultural Literature. Children's Advocate. <http://www.4children.org/issues/1997/september_october/> (12.4.2013)

SHORT, KATHY 2009: Critically Reading the Word and the World. Building Intercultural Understanding Through Literature. Bookbird 11 (2), 2-10.

SIMS, RUDINE I982: Shadow and substance. Urbana, Il: National Council of Teachers of English.

SIMS BISHOP, RUDINE 2007: Free Within Ourselves. The Development of African American Children's Literature. Westport: Greenwood Press.

SOLOMON, DANIEL, MARILYN WATSON \& VICTOR BATTISTICH 200 I: Teaching and Schooling Effects on Moral/Prosocial Development. Handbook of Research on Teaching. 4. painos. Ed. V. Richardson. Washington D.C.: American Educational Research Association.

TAPPAN, MARK I998: Moral education in the Zone of Proximal Development. Journal of Moral Education 27 (2), 141-161.

TOIVONEN, PIRJO-MAIJA I998: Uusien maailmojen viestit. Kirjallisuuden lukemisen semioottispsykolingvistinen teoria ja käytäntö. Turku - Helsinki: Helsinki University Press.

TURUNEN, MIKKO I999: Oppilas romaanin äärellä. Onko kirjallisuuskäsityksestä oltava huolissaan? Laulujen lumossa. Kirjallisuudentutkijoiden ja kirjailijoiden seireenilauluja professori Yrjö Varpiolle hänen 60-vuotispäivänään 7.11.1999. Toim. Y. Hosiaisluoma. Tampere: Tampere University Press. 